\title{
GENEOLOGI BAHASA DALAM HUMANIORA
}

\author{
Muhammad In'am Esha
}

Fakultas Humaniora dan Budaya, Universitas Islam Negeri Maulana Malik Ibrahim Malang

Email: essa_iesha@yahoo.com

\begin{abstract}
This paper studies the relation between language and humanities in the history of science perspective. Based on this study there are four findings. First, relation between language and humanities in the structure of science in this modern era is not able to be divided from the background of the development of studia humanitatis in the west. Second, development of humanities in the west relates to the vision of education for presenting humanizing curriculum. This is because of the fact that the studies and research in language and classical literatures is a necessity. Third, in Islamic civilization, the term humanities is unpopular, but essentially the studies of humanities (ex: language, literature, logic, art) have strategic position. Islamic civilization is text civilization (hadlarah al-nash) based on Koran and to understand it needs the tool, mainly language science. The existence of those sciences in Islamic civilization is very significant.
\end{abstract}

\section{Keywords}

History of Science, Humanities, Language

\section{Pendahuluan}

Sejak terjadi perubahan kelembagaan menjadi Universitas Islam Negeri, perguruan-perguruan tinggi Islam negeri (PTAIN) mempunyai peluang untuk mengembangkan fakultas-fakultas baru. Pembukaan fakultas baru itu merupakan upaya untuk meningkatkan tingkat relevansi dan kualitas pendidikan tinggi Islam negeri seiring dengan perkembangan di abad ini (Muzakki, 2006:60).

Dewasa ini, mudah ditemukan fakultas-fakultas baru yang dibuka seperti fakultas sains dan teknologi, fakultas kedokteran dan ilmu kesehatan, fakultas psikologi, fakultas ekonomi, dan fakultas ilmu-ilmu humaniora. Dahulu, tatkala masih berstatus sebagai IAIN/STAIN, meskipun perguruan tinggi ini bisa membuka program-program studi tersebut tentu tidak seleluasa tatkala menjadi universitas.

Seiring pengembangan fakultas dan program studi baru, berkembang juga pemikiran tentang struktur keilmuan yang dikembangkan di sebuah perguruan tinggi. Dua contoh yang bisa dikemukakan di sini misalnya, UIN Sunan Kalijaga Yogyakarta yang mengenalkan metafora jaring laba-laba untuk menggambarkan model pengembangan keilmuannya (Abdullah, 2004:7). Demikian juga di UIN Maulana Malik Ibrahim Malang yang mengenalkan pohon ilmu sebagai metafora struktur keilmuan yang dikembangkan (Suprayogo, 2006:17).

Hampir semua struktur keilmuan yang dikembangkan, pasti tidak dilepaskan dari ilmu-ilmu keislaman yang banyak berangkat dari teks-teks suci (hadharah al-nash) berdialog atau 
berintegrasi dengan ilmu-ilmu lain, yaitu: ilmu-ilmu kealaman (natural sciences), ilmu-ilmu sosial (social sciences), dan ilmu-ilmu humaniora (humanities studies).

Tulisan ini secara khusus ingin mengkaji sejarah ilmu humaniora yang dalam pandangan penulis kurang banyak dikaji. Selama ini kita sering mempertanyakan mengapa ilmu bahasa dan sastra dijadikan program studi yang masuk ke dalam fakultas humaniora. Tidak jarang juga ditemui adanya keberatan bahwa dasar-dasar tentang ilmu kehumanioraan seolah tidak tersentuh karena fakultas humaniora masih menggunakan kurikulum yang lama tatkala masih menjadi fakultas bahasa dan sastra.

Meskipun hal itu tidak salah karena bahasa dan sastra adalah bagian dari ilmu humaniora, tetapi kalau hanya mengacu pada disiplin itu tentu seolah mengerdilkan cakupan ilmu humaniora itu. Secara sistematik tulisan ini mencakup perihal humanisme dan humaniora, Ilmu-ilmu Humaniora, Geneologi Humaniora dan Kajian Bahasa Sastra.

\section{Sejarah Ilmu sebagai Perspektif}

Untuk mengetahui bagaimana sebuah disiplin keilmuan berkembang atau bagaimana melacak akar persoalan keterkaitan bahasa dan humaniora, maka hal yang tidak dapat dilepaskan adalah perspektif yang digunakan. Perspektif ibaratnya adalah sebuah jendela (window) tempat seseorang itu dapat melihat. Perspektif keilmuan memiliki bermacam-macam ragam. Ada sosiologi ilmu pengetahuan, filsafat ilmu pengetahuan, sejarah ilmu pengetahuan, dan sebagainya. Dalam kaitannya dengan pembahasan ini perspektif yang digunakan adalah sejarah ilmu pengetahuan.

Sejarah, seperti yang dijelaskan oleh Verhaak dan Imam (1997:163) merupakan disiplin ilmu yang relatif masih baru. Pada awal perkembangannya bidang ini justru ditangani dan dikembangkan para pakar dari bidang ilmu di luar sejarah. Baru pada beberapa dasawarsa belakangan bidang ini ditangani oleh para ahli yang memang mengkhususkan diri dalam bidang ini. Hal inilah yang pada gilirannya menjadikan disiplin ini mengalami perkembangan yang pesat.

Salah seorang yang terkenal dalam konteks sejarah ilmu adalah Thomas Kuhn. Berkat karyanya yang terkenal, the Structure of Scientific Revolution (1962), ia dikenal sebagai salah seorang tokoh sejarah ilmu. Kuhn sendiri awalnya bukanlah ahli sejarah, ia adalah pakar ilmu di bidang fisika. Baru dalam perkembangannya ia mendalami sejarah ilmu dan filsafat ilmu.

Dalam karya utamanya tersebut, Kuhn memaparkan tentang terjadinya revolusi ilmu pengetahuan yang menyertai perjalanan ilmu sepanjang sejarah. Melalui pendekatan sejarah, ia menemukan bahwa perkembangan ilmu pengetahuan pertama-tama bersifat revolusioner. Dalam kegiatan ilmiah, seorang ilmuan akan dibimbing oleh paradigma.

Paradigma itu membimbing kegiatan ilmiah dalam masa ilmu normal (normal science) di mana ilmuwan berkesempatan menjabarkan dan mengembangkan paradigma secara rinci dan mendalam, karena tidak sibuk dengan hal-hal mendasar. Dalam perkembangannya, ilmuwan bisa saja menghadapi fenomena yang tidak bisa dijelaskan dengan teorinya. Itulah yang disebut anomali. Jika anomali ini kian menggunung dengan intensitas yang tinggi, maka dapat menimbulkan krisis. Dalam krisis inilah paradigma bisa diteliti kembali atau dipertanyakan. Untuk mengatasi krisis itu, sang ilmuwan bisa memperluas cara-cara dalam paradigma itu atau 
mengembangkannya bisa juga menciptakan paradigma tandingan. Jika cara yang terakhir itu ditempuh maka terjadilah revolusi ilmiah (scientific revolution).

Demikianlah, sejarah ilmu telah memberi kontribusi untuk menjelaskan perkembanganperkembangan ilmu dalam konteks perjalanan panjang sejarahnya. Sejarah ilmu yang semula praktis menjadi semacam upaya untuk melihat urutan kronologis prestasi-prestasi ilmiah menjadi semakin kuat dan ketat. Penelitian berdasarkan sejarah ilmu telah memicu dorongan kuat di kalangan para pakar agar sebaiknya wajah ilmu dikonstruksi berdasarkan fakta-fakta sejarah (Verhaak dan Imam, 1997:164).

Sejarah ilmu dalam kenyataannya telah memberikan kekuatan untuk melihat secara lebih detail perkembangan-perkembangan ilmu sepanjang sejarah. Kita bisa melacak perkembangan dan bahkan pencabangan-pencabangan ilmu berdasarkan penglihatan atas dasar sejarah ilmu. Meskipun hal ini bisa terkait dengan sosiologi ilmu dan mungkin juga filsafat ilmu, tentu hal ini akan berbeda.

\section{Sejarah Ilmu Humaniora}

Meskipun ilmu-ilmu yang sekarang menjadi bagian penting dalam humaniora dapat dilacak sejak zaman Yunani, namun harus diakui jika kematangannya pada zaman modern ini tidak dapat dilepaskan dari fenomena humanisme yang berkembang di Barat. Sehingga, tatkala membincang persoalan humaniora sebenarnya tidak dapat dilepaskan dari berkembangnya humanisme di Barat.

Edward dalam Encyclopedia of Philosophy (t.t.:69) menjelaskan bahwa humanisme adalah sebuah gerakan filsafat dan literatur yang bermula dari Italia kemudian menjalar ke negaranegara Eropa lainnya. Gerakan ini menjadi salah satu faktor munculnya peradaban baru (renaissance di Eropa). Humanisme adalah sebuah paham yang memberikan tempat yang tinggi atas kedudukan manusia serta menjadikannya sebagai kriteria segala sesuatu. Dengan kata lain, humanisme menjadikan manusia subjek dan objek.

Kalau kita mengacu pada tiga tahapan perkembangan paradigma dalam sejarah pemikiran dalam peradaban manusia yaitu kosmosentrisme, teosentrisme dan antroposentrisme, maka humanisme lahir pada tahapan dimulainya paradigma manusia sebagai pusat (anthroposentrism) setelah alam pikiran Yunani kuno dan peradaban Barat beranjak dari kosmosentrisme abad klasik dan teosentrisme abad pertengahan.

Inilah yang dalam perspektif Magnis-Suseno (1992:60) dikatakan sebagai munculnya subjektivisme modern. Ia menjelaskan bahwa modernitas yang tengah kita alami sekarang ini berawal dari munculnya renaissance yang salah satu sebabnya adalah munculnya subjektivitas modern. Subjektivitas modern yang kemudian menggeser kecenderungan manusia yang bersifat kosmosentris dan teosentris menjadi antroposentrisme.

Cara memandang filsuf Yunani bersifat kosmosentris. Mereka mencari dasar realitas dalam unsur-unsur kosmos atau alam raya. Thales (624-548 SM) berpendapat bahwa dasar realitas adalah air. Anaximenes (590-528SM) mengatakan dasar realitas adalah udara (Poedjawijatna, 2002:23). Itulah dua contoh produk pemikiran Yunani yang bersifat kosmosentris. Pada abad pertengahan, pandangan kosmosentris disingkirkan oleh pandangan theosentris: semua dilihat dari segi Allah. Manusia memahami diri sebagai salah satu unsur meskipun dalam hierarkhi ciptaan Allah sebagai yang tertinggi. Dua model pandangan ini yang kemudian digantikan dengan pandangan anthroposentris. Manusia ditempatkan sebagai pusat dunia. Manusia tidak 
lagi memahami dirinya sebagai bagian dari alam raya tetapi sebagai subjek yang berhadapan dengan alam semesta. Pandangan ini adalah awal kelahiran humanisme. (Magnis-Suseno, 1992:61).

Meskipun dalam beberapa literatur dijelaskan adanya pembedaan antara humanisme skolastik dan humanisme renaissance, namun pada tulisan ini akan difokuskan pada model humanisme yang kedua. Seperti yang dijelaskan oleh Tjaya (2004:19) bahwa humanisme pada awalnya merupakan sebuah gerakan literer dan berwawasan pendidikan. Hal ini secara jelas dapat dipahami tatkala kita melacak akar kata humanisme itu sendiri.

Kata humanisme secara geneologis mempunyai proses penafsiran dan penurunan kata yang cukup panjang. Terdapat tiga istilah yang perlu diketahui untuk memahami istilah tersebut. Pertama, kata humanismus. Kata ini diciptakan oleh ahli pendidikan Jerman, F.J. Niethammer, untuk menunjukkan pada tekanan pengajaran tentang karya-karya klasik berbahasa Latin dan Yunani di sekolah-sekolah menengah yang sedang dilanda kurikulum pendidikan yang bersifat praktis dan berorientasi pada sains. Istilah tersebut merupakan turunan dari istilah kedua, humanista untuk menunjuk pada para professor humanisme di universitas-universitas pada era renaissance. Kata humanista sendiri merupakan turunan dari kata yang lebih tua lagi, dan ini istilah ketiga, yaitu humanities atau studia humanities. Istilah ketiga ini dipakai untuk menunjuk pada pendidikan liberal art dengan menggunakan karya-karya Romawi klasik seperti Cicero dan Gellius. Istilah yang ketiga inilah yang kemudian dikenal dengan istilah humaniora.

Dalam sejarahnya, gerakan humanisme yang muncul bergandengan erat dengan pendidikan tidak dapat dilepaskan dari realitas yang terjadi di Eropa pada saat itu. Di Eropa Utara pada akhir abad pertengahan (Abad 12 dan 13 M.), muncul sekolah-sekolah katredal yang merupakan pusat pendidikan bagi para calon imam katolik. Di sekolah-sekolah ini diajarkan tujuh liberal art seperti bahasa dan membaca karya-karya klasik. Pada akhir abad ketiga belas, berdiri universitas dengan art sebagai fakultas utama. Di rumah baru ini dikembangkan filsafat dan logika serta sains berdasarkan pikiran Aristoteles.

Pada awal abad kelima belas para humanis mulai melakukan ekspansi studi humanistik ke dalam bidang-bidang baru yang kemudian mereka menyebutnya sebagai studi kemanusiaan (the humane studies) atau studi-studi yang selaras dan patut dilakukan oleh manusia (studia humanitatis, studia humaniora). Meningkatnya posisi penting dari keilmuan ini pada abad pertengahan tersebut memicu perkembangan ilmu-ilmu humaniora di Barat.

Humaniora merupakan cabang ilmu pengetahuan yang bertujuan mencapai kemanusiaan yang sesungguhnya atau manusia yang lebih berbudaya. Menurut J. Drost (Masruri, 2005:50), humaniora adalah ilmu-ilmu pengetahuan yang bertujuan membuat manusia lebih manusiawi dan berbudaya.

Dikatakan demikian karena berawal dari keprihatinan yang muncul di Barat di mana ilmu-ilmu praktis dan sains mengemuka sehingga memunculkan gerakan humanisme melalui pendidikan sehingga kajian terhadap humaniora merupakan sesuatu yang sentral dalam proses pembangunan khususnya di abad teknologi informasi sekarang ini. Studi humaniora membantu manusia untuk menangkap makna dari pengalaman hidup dan menyajikan jalan bagi pemahaman atas aktivitas kehidupan.

Ilmu humaniora membina kemampuan manusia untuk berimajinasi. Manusia pada hakikatnya mengandung unsur-unsur yang lebih dari sekedar penerapan metode yang analitik dan kuantitatif 
serta eksperimental. Berbagai kebutuhan, ambisi, rasa frustasi, ketidakmampuan, tidak dapat diamati sekedar dari angka-angka kuantitatif. Semua itu hanya dapat dipahami melalui proyeksi imajinatif (Masruri, 2005:51). Di sinilah posisi penting dan tujuan hakiki dari ilmu humaniora.

Dalam pengertian klasik, humaniora tidak lain merupakan ilmu bahasa dan sastra Latin dan Yunani yang dalam perkembangannya mencakup keilmuan yang beragam: ilmu agama, filsafat, bahasa, sastra, pendidikan, sejarah, dan seni. Pendidikan dalam ilmu-ilmu humaniora bertujuan untuk meluruskan cara berpikir para intelektual agar mereka tidak hanya menguasai bidang sains dan teknologi tetapi juga berbudaya dan berwatak (Masruri, 2005:149).

Dalam perspektif ini, sebenarnya ilmu-ilmu humaniora tidak saja diperuntukkan bagi mahasiswa yang studi di Fakultas Humaniora tetapi juga di seluruh Fakultas. Pendidikan budaya dan watak adalah sesuatu yang manusiawi dan harus dirasakan semua mahasiswa.

Proses pembacaan sejarah misalnya, akan membawa manusia keluar dari kungkungan ruang dan waktu. Fiksi, sejarah, dan puisi merupakan karya yang dapat menuntun manusia berempati terhadap tokoh yang diciptakan. Ia juga mengajak manusia untuk memahami perjuangan, kejayaan, dan kelemahan tragis. Demikian juga melalui novel, biografi, drama, manusia akan mengalami sendiri kegembiraan dan penderitaan sesamanya. Dengan ilmu humaniora, menusia akan dapat merasakan kemanusiawiannya melalui pengenalan dengan sesamanya (Masruri, 2005:151).

\section{Geneologi Bahasa dalam Humaniora}

Pada paparan berikut ini menjelaskan posisi penting kajian bahasa dan sastra menjadi di dalam studi ilmu humaniora. Dengan pemaparan ini diharapkan mampu menjawab pertanyaan kecil terkait persoalan mengapa bahasa dan sastra sedemikian sentral dalam ilmu humaniora.

Jika dicermati dari hakikat ilmu humaniora, setidaknya bisa dipahami bahwa ilmu humaniora tidak lain merupakan ilmu yang berusaha untuk menjadikan manusia menjadi lebih manusiawi, berwatak dan berbudaya. Ilmu ini penting karena menyangkut aspek terdalam dalam peri kehidupan manusia, yakni bagaimana manusia itu bisa menjadi manusia yang sesungguhnya.

Kalau berpijak pada pertanyaan dasar: Apakah manusia itu?, maka ditemukan berbagai macam jawaban tentang apa manusia. Tetapi kalau dirujuk pada pemahaman yang sangat umum, maka manusia biasanya didefinisikan sebagai al-hayawan al-natiq atau hewan yang berbahasa. Jadi, kemampuan berbahasa yang membedakan manusia dari makhluk yang lain. Dengan kemampuan berbahasa, ia bisa berkomunikasi, berinterakasi, dan berbudaya. Tidak mengherankan jika para ahli bahasa menyatakan bahwa hakikat terdalam dari manusia tidak lain adalah bahasa.

Karena bahasa menjadi bagian penting dari manusia, maka seiring dengan tujuan hakiki dari ilmu humaniora, bahasa lalu menjadi bagian penting dalam kajian ilmu humaniora. Terlebih jika disandingkan dengan kenyataan adanya agama yang memberikan ajarannya melalui wahyu bertujuan untuk memanusiakan manusia, maka keberadaan bahasa sebagai piranti memahami wahyu menjadi sesuatu yang memang niscaya.

Dalam konteks di atas, bisa dimengerti mengapa ilmu-ilmu humaniora seperti yang terjadi di Barat berawal dari pendidikan dalam bidang kebahasaan. Tatkala di Barat berdiri sekolahsekolah katredal dan universitas-universitas, maka yang utama diajarkan adalah keahlian berbahasa. Hal ini tidak lain karena di samping kebutuhan nyata dalam masyarakat kota pada saat itu, keahlian bahasa menjadi penting bagi kepentingan agama. 
Dalam konteks tradisi Islam, perkembangan ilmu bahasa sedemikian sangat penting dan mendasar. Seperti yang dituturkan dalam ahli-ahli sejarah, bahwa ilmu yang berkembang lebih awal pada fase-fase perkembangan Islam adalah ilmu kebahasaan. Ini bisa dimaklumi karena memang dalam kenyataan masyarakat muslim yang dalam bahasa Rippin (1990) disebut sebagai scripturalis faith yaitu masyarakat yang keimanannya sangat dipengaruhi oleh teks-teks wahyu, menaruh perhatian penting terhadap bahasa sebagai piranti untuk memahami wahyu.

Al-Qur'an sebagai wahyu bagi umat Islam telah menjadi teks sentral dalam peradaban. Dasardasar ilmu dan budaya Islam tumbuh dan berdiri di atas landasan di mana teks sebagai pusatnya. Peradaban teks (hadharah al-nash) yang tercipta dalam konteks ini bagaimana pun tidak dapat dilepaskan dari ilmu kebahasaan dimana piranti pemahaman teks itu berada (Zaid, 2005: 1).

Meskipun term humaniora tidak populer dalam masa kejayaan Islam, tetapi bisa dipastikan bahwa ilmu-ilmu yang sekarang ini menjadi cabang ilmu humaniora seperti bahasa, sastra, filsafat, sejarah, ilmu agama, seni telah berkembang pesat pada masa itu. Terkait dengan ini, sedemikian penting ilmu bahasa saat itu, al-Farabi dalam klasifikasi keilmuannya telah menjadikan ilmu bahasa dan cabang-cabang awal ilmu kehumanioraan seperti retorika dan seni pada posisi urutan pertama dan kedua.

Berikut klasifikasi keilmuan seperti yang dibuat oleh al-Farabi dalam kitabnya ihsha' al- ulum (Bakar, 1988: 146):

1. Ilmu Bahasa ('ilm al-lisan) terdiri dari ilmu sarf, ilmu nahwu, khat, qira'ah dan kaidah-kaidah puisi.

2. Ilmu Logika ('ilm al-mantiq) terdiri dari silogisme (qiyas), demonstrasi (burhan), seni retorika (al-khitabah), seni puisi dan lain-lain.

3. Ilmu Matematis, terdiri dari aritmatika atau ilmu hitung ('ilm al-'abad), Geometri ('ilm alhandasah), optika ('ilm al-manazir), ilmu perbintangan ('ilm al-nujum), musik ('ilm almusiqa), ilmu tentang berat ('ilm al-asqal), dan ilmu tentang pembuatan alat ('ilm al-hiyal).

4. Fisika ('ilm at-tabi'i) terbagi menjadi delapan bagian, yaitu: (1) prinsip-prinsip benda alami (al-sam'at-tabi'i), (2) prinsip-prinsip unsur dan benda-benda sederhana (al-sama' wa al'alam), (3) penciptaan dan penghancuran benda-benda alami (al-kaun wa al-fasad), (4) reaksi yang dialami oleh unsur-unsur saat membentuk benda senyawa (al-asar al-'alwiyyah), (5) sifat-sifat benda senyawa (6) mineral (al-ma'adin), (7) tumbuhan (al-nabat), dan (8) binatang termasuk manusia (kitab al-hayawan wa kitab al-nafs).

5. Metafisika (al-'ilm al-ilahi)

6. Ilmu Politik (al-'ilm al-madani) berkaitan dengan (a) kebahagiaan dan kebajikan manusia dan (b) etika dan teori politik.

7. Yurisprudensi (al-'ilm al-fiqh) berhubungan dengan ritus-ritus, praktik-praktik religius, dan pemerintah moral-legal.

8. Teologi dialektis ('ilm al-kalam).

Posisi penting ilmu bahasa karena kedekatannya dengan masalah keagamaan, nampaknya juga sangat kental terjadi di Barat pada abad pertengahan. Tatkala sekolah-sekolah katedral dan universitas-universitas tumbuh untuk menyiapkan para imam dan profesional, liberal art yang di antaranya mengajarkan retorika dan karya-karya klasik Yunani dan Latin, menjadi menu wajib. Dengan kurikulum semacam ini mereka ingin meraih citra masyarakat Kristen yang baik. Terkait dengan hal ini Tjaya (2004: 32) menuturkan: 
Penguasaan kefasihan berbicara dapat digunakan orang-orang Kristen dalam zaman renaissance untuk membuat generasi mereka sepenuhnya memeluk kebenaran moral dan religius yang sangat diperlukan bagi pembaruan pribadi dan sosial. Keinginan para humanis untuk meniru gaya elegan dan kefasihan berbicara para pengarang klasik telah membawa mereka pada pencarian teks-teks kuno. Pencarian ini, bersama dengan studi bahasa, membuka mata mereka terhadap bidang studi lainnya.

Jelaslah, bahwa visi ilmuan humaniora untuk menjadikan manusia lebih manusiawi, berwatak dan berbudaya tidak dapat dilepaskan dari visi keagamaan. Kekentalan hubungan bahasa dan humaniora juga dapat ditelisik bahwa keduanya memiliki hubungan terpilin yang sulit dilepas. Visi humaniora tidak akan dapat dicapai tanpa peran bahasa sebagai piranti yang paling penting. Tidak heran jika dalam sejarah pengetahuan terdapat dorongan untuk mengejawantahkan visi humanistik yang dengan itu manusia dipacu untuk mengembangkan ilmu-ilmu kebahasaan.

Sedemikian pentingnya, tidak salah jika filsuf besar Islam seperti al-Ghazali dalam klasifikasi keilmuannya menjadikan ilmu bahasa sebagai bagian penting dalam ilmu syar'iyyah. Berikut klasifikasi keilmuan menurut al-Ghazali dalam Ihya Ulum al-Din (Garnet dan Anawati: 1978: 208):

1. Ilmu Syari'ah (al-'ilm al-syar'i)

a. Ilmu tentang prinsip-prinsip dasar (al-'usul), terdiri: ilmu al-Qur'an. Sunnah (tradisitradisi Nabi), konsensus (Ijma'), dan ijma’ para sahabat (asar al-sahabat).

b. Ilmu tentang cabang-cabang (furu'): terdiri fiqh, yaitu ilmu yang berkaitan dengan persoalan-persoalan duniawi (al-umuur al-duniawiyyah), dan 'ilm ahwal al-qalb, yaitu ilmu yang berkaitan dengan persoalan-persoalan akherat (al-umuur al-ukhrawiyyah).

c. Ilmu-ilmu pengantar atau ilmu alat (al-muqaddimaat), antara lain terdiri ilmu bahasa dan tulis-menulis.

d. Ilmu-ilmu pelengkap (mutammimaat) terdiri dari: (1) Ilmu-ilmu Qur'an, termasuk di dalamnya ilmu tafsir, ilmu qira'at dan usul fiqh; (2) Ilmu Hadis, (3) Asar dan Akhbar, yakni biografi yang berhubungan dengan kehidupan para nabi, sahabat dan orang-orang terkenal; (4) Ilmu Kalam, (5) Filsafat yang terdiri dari empat bagian, yaitu: geometri dan matematika, mantiq, metafisika dan fisika.

2. Ilmu Non Syari'ah (al-'ulum ghair al-syar'i)

a. Yang terpuji (mahmuudah); meliputi: (1) ilmu yang bersifat fardu kifayah, seperti ilmu kedokteran dan matematika; (2) ilmu yang bersifat utama (fadilah), seperti kemendalaman dalam ilmu kedokteran dan matematika.

b. Yang tercela (mazmuumah), seperti ilmu sihir.

c. Yang boleh (mubah), seperti syair dan sejarah para nabi dan sahabat.

Ilmu syar'iyyah dalam perspektif al-Ghazali adalah ilmu-ilmu yang wajib dipelajari karena jika tidak tentu akan meruntuhkan sendi-sendi manusia itu sebagai manusia yang seutuhkan dan manusia yang religius.

\section{Penutup}

Paparan di atas setidaknya memberikan beberapa pemahaman terkait dengan geneologi bahasa dan humaniora. Pertama, keterpautan antara bahasa sebagai bagian dalam struktur keilmuan humaniora yang saat ini populer dalam khazanah keilmuan modern, tidak dapat dilepaskan dari perkembangan sejarah keilmuan humaniora (studia humanitatis) yang terjadi di Barat. Kedua, 
dalam perspektif sejarah keilmuan humaniora yang terdapat di Barat, perkembangannya tidak dapat dilepaskan dari visi pendidikan kaum humanis yang ingin mengembangkan kurikulum pendidikan dalam rangka meneguhkan sikap moral (manusia yang berbudaya dan berwatak). Hal inilah yang kemudian menuntut mereka untuk mengkaji karya-karya klasik seperti sastra dan filsafat. Ketiga, meskipun dalam tradisi keilmuan Islam term humaniora tidak dikenal, namun secara esensi pengembangan ilmu-ilmu yang saat ini menjadi cabang ilmu humaniora telah menempati posisi yang strategis. Islam sebagai agama wahyu memerlukan piranti bahasa untuk memahami teks wahyu tersebut. Sehingga, keberadaan ilmu bahasa menjadi sangat signifikan.[]

\section{DAFTAR PUSTAKA}

Abdullah, Amin. 2004. Kerangka Dasar Keilmuan dan Pengembangan Kurikulum UIN Sunan Kalijaga Yogyakarta. Yogjakarta: Pokja Akademik UIN Suka Yogyakarta.

Bakar, Osman. 1988. Hierarki Ilmu, Membangun Rangka-Pikir Islamisasi Ilmu, terj. Purwanto, Bandung: Mizan.

Edwards, Paul. Tanpa tahun. Encyclopedia of Philosophy, jilid IV.

Gardet, Louis dan G, Anawati. 1978. Falsafah al-Fikr ad-Dini Baina al-Islam wa al-Masihiyyah, terj. Subhi Salih dan Farid Jabr, Beirut: Dar al-'Ilm Lilmalayin.

Masruri, Siswanto. 2005. Humanitarianisme Soedjatmoko: Visi Kemanusiaan Kontemporer. Yogyakarta: Pilar Media.

Muzakki, Akh. 2006. "Pasar Pendidikan Islam: Tantangan PTAI di Era Globalisasi” dalam Perta No. 01.

Poedjawijatna. 2002. Pembimbing Ke Arah Alam Filsafat. Jakarta: Rineka Cipta.

Ripin, Andrew. 1990. Muslims, Their Religius Belifs and Practices, New York - London: Routledge, 1990

Suprayogo, Imam. 2006. Paradigma Pengembangan Keilmuan Islam. Malang: UIN-Malang Press.

Tjaya, Thomas Hidya, 2004. Humanisme dan Skolastisisme: Sebuah Debat. Yogyakarta: Kanisius.

Verhaak, C. dan R. Haryono Imam. 1997. Filsafat Ilmu Pengetahuan. Jakarta: Gramedia Pustaka Utama.

Zaid, Nasr Hamid. 2005. Tekstualitas al-Qur'an: Kritik terhadap Ulumul Qur'an. Yogyakarta: LKiS. 